\title{
Political Theory of Societal Association: Case of the Failed State of Syria, Part 1
}

\section{Frederick Betz}

Institute for Policy Models, Seattle, WA, USA

Email: fbetz@venture2 reality.com

How to cite this paper: Betz, F. (2019) Political Theory of Societal Association: Case of the Failed State of Syria, Part 1. Open Journal of Social Sciences, 7, 271-296. https://doi.org/10.4236/jss.2019.711020

Received: October 8, 2019

Accepted: November 24, 2019

Published: November 27, 2019

Copyright $\odot 2019$ by author(s) and Scientific Research Publishing Inc. This work is licensed under the Creative Commons Attribution International License (CC BY 4.0).

http://creativecommons.org/licenses/by/4.0/ (c) (i) Open Access

\begin{abstract}
One of the major issues in studies of civilization has been whether "progress" is possible in the evolution of societies. In a previous paper, we defined a metric for measuring progress in civilization and illustrated how the international court for war crimes originated as an institutionalization of progress [1]. Yet in contrast, "regress" can occur in civilization. And in the early twenty-first century, "regress as a failed state" turned out to be an important issue. Global civilization is presently composed of many states defined by territories and interacting in international trade through global corporations. The puzzle is why, in this interconnected global society, are there failed states-regressions of civilization? We analyze the history of Syria, as a failed state in the $21^{\text {st }}$ century. In this historical case, we can test the validity of the modern political theory of association, as to how and why such political regression occurs. Historical studies provide the empirical basis for grounding (verifying) social science theories, when theories are expressed in analytical frameworks that are generalized across different historical cases. In this research, we formalize some basic concepts of modern political science theory in a 3-dimensional typology-in order to analyze the dynamics of modern state or nation in formation or dissolution. This is the first paper (of four) analyzing the failure of the Syrian state. Four papers are required due to the complicated sequence of events in the history of Syria: 1) from territory in the Ottoman Empire into European colonial states, 2) to independent states, 3) to a near collapse under a terrorist caliphate, and 4) to refugee impacts on its former colonial occupiers.
\end{abstract}

\section{Keywords}

Civilization, Failed States, Political Theory, Middle East, Colonialism, Ottoman Empire

\section{Political Theory of Association}

Francis Fukuyama summarized the political-economic theory as: firstly, a ten- 
sion between different groups in government formation (tribes, states, nations, and militia) and secondly, a process of government occurring in different types (ideological dictatorship, democracy, rent-seeking state, authoritarian) [2].

Also as basic theory fundamental to government, Fukuyama proposed two sets of dichotomies: a) state and nation, b) tribe and culture. Fukuyama wrote: "Virtually all human societies were once organized tribally. Yet over time, most developed new political institutions which include a central state that could keep the peace. The Vikings, the Celtic peoples the Romans were all originally organized into tribes much like those that still exist in Afghanistan, central Iraq and Papua New Guinea. So were the Chinese, Indians, Arabs, Africans, and virtually all other peoples of earth. They owed primary obligation not to a state but to a kinfolk, they settled disputes not through courts but through a system of retributive justice, and they buried their dead on property held collectively by groups of kin. These tribal societies developed political institutions. First and foremost was the centralized source of authority that held an effective monopoly of military power over a defined piece of territory-what we call a state." [3].

In modern times, the relevance of these two basic concepts of tribe and state can be seen in the recent history of civil war in Lebanon. The Lebanese civil wars occurred from 1975 to 1990. Before, Lebanon was a state with Sunni Muslims and Christians sharing power, both being the majorities of population in the cities. Shia Muslims were mainly in farming villages in the south of Lebanon. In the mountains were populations of Druze and Christians. Also Palestinian refugees had fled from Israel into the south of Lebanon, just across the border. There, organized by the Palestine Liberation Organization (PLO), they launched occasional attacks on Israel settlers. In 1975 continuing to 1989, fighting occurred between Maronite Christians and PLO forces; and Muslim groups in Lebanon sided with the PLO. The civil wars tore Lebanon apart, with militias fighting each other.

Thomas Friedman wrote: "Lebanese were forever asking me whether I had visited Beirut before the civil war began. 'No,' I would say, I never had the pleasure.'. Then they would get a faraway look, and a mist of reminiscence would fog their eyes, and they would wax eloquent about how 'life was so beautiful then-Lebanon really was the Switzerland of the Middle East'. It certainly looked that way on the postcards: snowcapped mountains towering over Beirut, a bank on every corner and a parliament with all the trappings of a European-style democracy. But how could a city go from being a vision of heaven to a vision of hell practically overnight? Because it was too good to be true; because Beirut in its heyday was a city with a false bottom." [4].

The territory of Lebanon was beautiful, and it had a long tradition of trading in a pluralistic society. But after the French colonialization of Lebanon, it never really was constructed to be a stable state. Thomas Friedman wrote: "Lebanon was never the Switzerland of the Middle East. It was always the Tower of Babel. The first and largest of these wars was the one that began in 1975 and culminated in the Shouf in 1984; the civil war over who should control the Lebanese 
government, which was fought out between the Christian and Muslim militias. It was this confrontation which had broken Beirut and Lebanon in half. The second civil war began in the late 1970s within the two halves of the country. It involved Muslims fighting against Muslims and Christians fighting Christians to decide which Muslims and which Christians would control their respective halves of Lebanon. The third civil war was a silent civil war. It began in the early 1980s and pitted all the Christian and Muslim militiamen who benefited from Lebanon's chaos on the one side and all the Lebanese civilians who suffered from that chaos on the other." [4].

Thomas Friedman experienced the rampage of militia: "My first glimpse of Beirut's real bottom came at the Commodore Hotel bar on February 7, 1984-the day after the Druze and the Shiite Amal militias had seized control of West Beirut from the Lebanese army. Groups of Shiite militiamen, belonging to the radical pro-Iranian organization Hezbollah (Party of God), had gone on a rampage that morning, ransacking heathen bars and whorehouses just off West Beirut's Hara Street. I was enjoying a "quiet" lunch in the Commodore restaurant that day when I heard a ruckus coming from the lobby. I turned around and saw a tall, heavyset Shiite militiaman with a black beard, a wild look in his eyes, and an M-166 in his hands heading for the bar. He stalked behind the bar and began smashing every liquor bottle and glass with his rifle butt. He didn't miss a single one. When he was done, he stalked out of the lobby, leaving behind a small lake of liquor on the floor and a stunned crowd of journalists frozen to their chairs. The scene was terrifying on many levels. He had Truth with a capital T, and he was from a party of God, and nothing could stop him. He was a Lebanese. He had been living for years in the same city with us, and we really never knew he was. With his rifle butt, he not only smashed the Commodore bar but also right through Beirut's false bottom. to reveal a tribal wrath that had been building in intensity for decades beneath the surface." [4].

From this illustration (and others similar in the recent history of the Middle East), one can see that political science concepts, such as a "tribe" or a "state" are still basic to modern history and to the discipline of political science.

Fukuyama also drew upon modern socio-biology to distinguish between two other kinds of societal association: genetic and altruistic. Francis Fukuyama wrote: “...political order is rooted in human biology. Natural human sociability is built around two phenomena: kin selection and reciprocal altruism. The first is a recurring pattern by which sexually-reproducing animals behave toward one another in proportion to the number of genes they share (genetic). Reciprocal altruism involves an exchange of favors or resources between unrelated individuals (altruistic). Both behaviors are not learned but genetically coded and emerge spontaneously as individuals interact. Human beings, in other words, are social animals by nature." [3].

Gene-sharing creates societal association by kinship structures. Reciprocal altruism creates societal association by trust in reciprocal dealings between individuals. One important kind of reciprocal altruism arises from sharing a religion. 
Francis Fukuyama wrote: "Tribal societies can mobilize hundreds or thousands of kinsmen on a moment's notice. It is likely, then, that the first society was able to knit together large kindreds through religious belief in ancestors. Religion plays an important functional role in facilitating large scale collective action.” [3].

This dichotomy between kinship and religion (genes and reciprocal-altruism) still plays an important role in societal association in the Middle East. About the role Shiite religion played in the conflicting associations in Lebanon, Thomas Friedman wrote: “This turbulent pool was made up largely of Lebanese Shiites. The Shiites of Lebanon were the country's perpetual underclass, a rural people for centuries seemed to silently accept their role as Lebanon's beasts of burden. But the Palestinian-Israeli fighting in south Lebanon in the seventies and eighties drove thousands of these Shiites from their native villages in the south to shantytowns on the outskirts of Beirut. By the early 1980s, the Shiites of Lebanon were the largest single religious community in the country, making up close to half the total population. By 1984, the Shiites of Lebanon were tired of waiting for the city's gates to open. The Israeli invasion and the Shouf war had shown them how weak the Lebanese state was and the Iranian Islamic revolution had shown them the power which Shiites could exert in the world. It was time for a cleansing. West Beirut has been dominated by the Shiites ever since." [4] (Friedman, 1989).

As shown in Figure 1, to formalize this theory of "political association", one can take the two conceptual dichotomies (kinship-reciprocity plus tribe-state and decentralized plus centralized-power) to define a theoretical taxonomy of Fukuyama's types: Tribe, Religion, State, and Nation.

Political association in a Tribe depends upon kinship association and decentralized power from tribe to tribe. In contrast, a State depends upon the centralization of power by the military supremacy of one tribe over other tribes in the territory of the state. In a feudal state, the militarily dominant tribe has been called the feudal aristocracy and the dominated tribes in the territory as peasants. Religion is a way to associate across tribes through a shared reciprocal

\begin{tabular}{|c|c|c|}
\hline \multicolumn{2}{c}{ THEORETICAL TAXONOMY OF POLITICAL ASSOCIATION } \\
& KINSHIP ASSOCIATION & RECIPROCAL-ALTRUISM ASSOCIATION \\
\cline { 2 - 3 } $\begin{array}{c}\text { DECENTRALIZED } \\
\text { POWER }\end{array}$ & $\begin{array}{c}\text { TRIBE } \\
\text { INFRASTRUCTURE } \\
\text { \& PROCESSES }\end{array}$ & $\begin{array}{c}\text { RELIGION } \\
\text { INFRASTRUCTURE } \\
\text { \& PROCESSES } \\
\text { CENTRALIZED } \\
\text { POWER }\end{array}$ \\
\cline { 2 - 3 } & $\begin{array}{c}\text { STATE } \\
\text { INFRASTRUCTURE } \\
\text { \& PROCESSES }\end{array}$ & $\begin{array}{c}\text { NATION } \\
\text { INFRASTRUCTURE } \\
\text { \& PROCESSES }\end{array}$ \\
\hline
\end{tabular}

Figure 1. Taxonomy of political association. 
belief in the supernatural religious view of society and with power dispersed throughout the tribes. The concept of a nation is one of centralized power but unified not by kinship but by a shared reciprocal-altruism of patriotism.

We now test (validate) this theoretical taxonomy of political science by history, particularly the history of the "state" of Syria. In this validation, we can examine the hypothesis of whether Syria was ever a "nation"-and if not, whether this was basic to the eventual failure of the "state"?

\section{Nineteenth Century Political Association in Europe and Ottoman Empire}

The concept of a "nation" compared to that of a "state" is important in histories of Europe and the Ottoman Empire. We test the empirical validity of this taxonomy-of-political-association by examining the rise of the states of the modern Middle East-out of the dissolution of the Ottoman Empire. And for the comparison of theory-to-historical-reality, we will use the research technique of societal dynamics to analyze the origin of the state of Syria [5]. This research technique depicts how in the history of a society, "change-events" alter a society's stasis of a "structure-function" model. The two historical events which changed Ottoman society toward the end of its Empire are shown in Figure 2.

After these two historical "change-events", the societies of the contemporary Middle East devolved from that earlier "structural-functional" society of the Ottoman Empire. There were two key "change-events" in the Ottoman Empire prior to the establishment of the state of Syria in 1920: 1) in 1839, the modernization of the Ottoman State began and 2) in 1914, the first World War began resulting eventually in the dissolution of the Ottoman State.

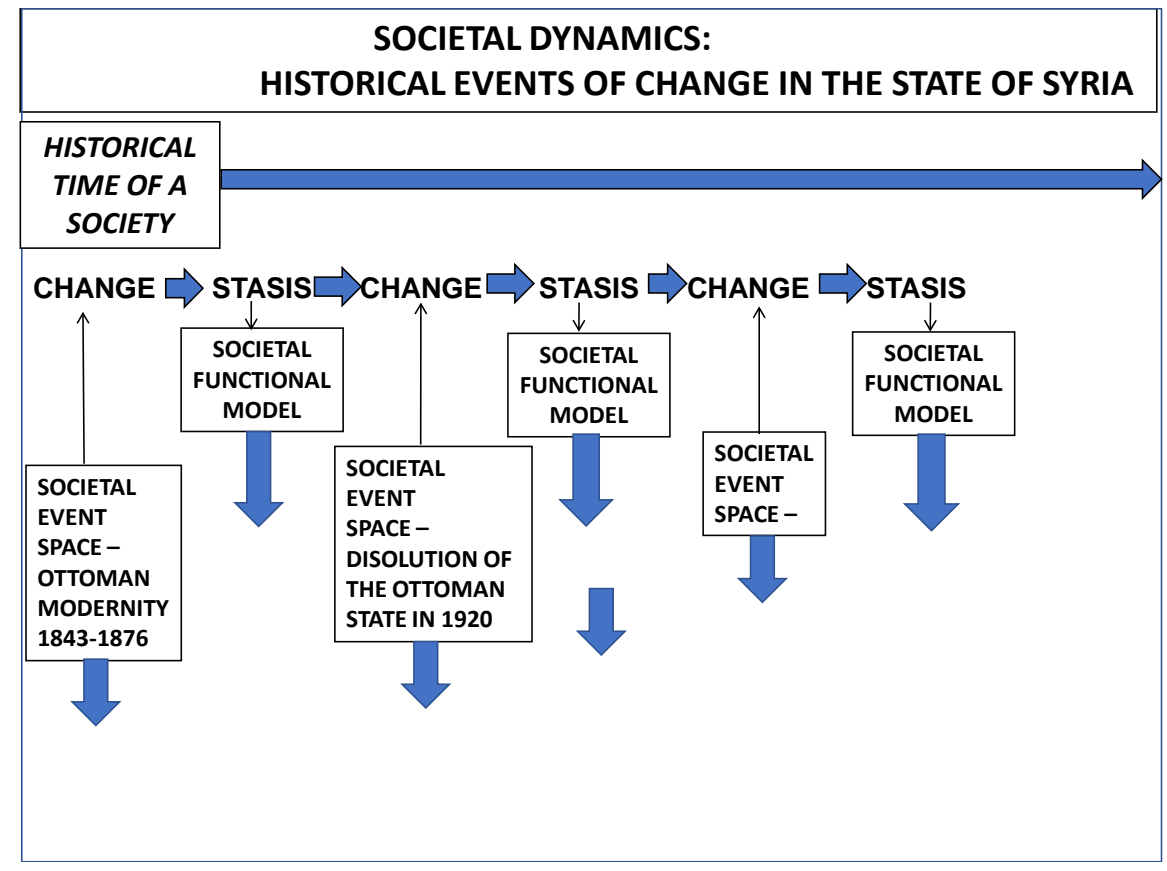

Figure 2. Change-events in the end of the Ottoman Empire. 
Basic scientific concepts about what is a "society" have been formulated in the social science disciplines of sociology and political economy. Sociology has depicted modern societies as "structure-functional" objects [6]. This means that all societies evolve organized patterns of behavior (structures) which enable the behaviors of participants to gain "functional" benefits. Sociologists have named this depiction of a society as a "structural-functional model". In addition, economists have named the economic functional benefits as being good for a particular individual and/or good for all individuals: "individual-good" and/or "public-good". Therefore, a sociological and economic perspective on society is to see structural-functional organizations of participants that create both private and public good. Also, a political science perspective adds that in such societies do the societal structures provide the functions for "just society", a situation of equal rights for all lawful citizens of a society?

The Ottoman Empire began in the 1400s and expanded into the 1700s, reaching the gates of Vienna in the 1735. But in the 1800s, retreat in the size of its territory began, with losses to Russia and to the Austrian-Hungarian Empire. The modernization of the Ottoman Empire began from 1843-1876, as a first significant change-event for future Syria. This modernization of the government of the Empire would provide structural and functional forms inherited by the Syrian state. The second key change event was the dissolution of the Ottoman Empire, after its military loss in World War I.

The reforms of European states and the Ottoman state occurred after the collapse of Napoleon's French Empire, when Napoleon's army was destroyed retreating from Russia. But the older style of government in Europe and the Ottoman had been shown to be obsolete by the triumphs of Napoleon's military. This used to be the form of a state: an absolute monarchy, fielding a mercenary army, funded by the monarch. The "reform" of such a monarchical state was to transform it into a "nation", with a conscripted and patriotic army.

Of this European-wide reform of monarchical states, Michael Provence wrote: "Ottoman modernity was part of a universal discourse of nineteenth century modernization, militarism, and progress... The features of nineteenth century modernity were similar in all the eventual belligerents of the Great War of 1914; mass standing armies, conscription, state education, census-taking, state networks of communication and mobilization, mass collective ritual and participation, the notion of popular sovereignty, and collective sacrifice for God, king and country and the living body of a nation." [7].

The impact of the French Revolution and Napoleon's seizure of government and subsequent military domination in Europe impressed the European states. They all recognized the urgent need for modernizing monarchical "states" into patriotic "nations".

Michael Provence wrote: "the central feature of the nineteenth century (in Europe) was a re-negotiation and codification of the contract between the state and its subjects or citizens. Similarly in the Ottoman Empire, the Tanzimat decrees in 1839 began the process there-declaring the equality of imperial sub- 
jects before the law, and introducing the idea that the sovereign's right to government flowed, at least in part, from the fulfillment of a contract with, and eventually from the consent of, the governed." [7].

This was the central principle in the conceptual transformation of the idea of the "state" into that of a "nation". The population of a nation were all to be regarded as citizens; and their loyalty to the government was expected. But this expectation to become real did depend on the citizens perceiving that the government was serving the people. Prior to the French Revolution, this idea was articulated by the French philosopher, Jean-Jacques Rousseau, as a "social contract" between the government and the governed [8]. In 1800, the military weakness of the European states' mercenary armies was demonstrated in their defeats by the patriotic-conscripted army of the French revolution, under Napoleon.

Michael Provence wrote: "In studying Prussian conscription, Ute Frevert identified a series of common themes among the major states of post-Napoleonic Europe. All states recognized the need for standing armies and all reluctantly embraced mass conscription. The imperative to conscript soldiers forced monarchs and war ministers to slowly concede to changes in the relation between state and subject. Through the middle decades of the nineteenth century, state builders, as diverse as Napoleon, Muhammad Ali of Egypt, Friedrich Wilhelm III of Prussia, and Ottoman Sultan Mahmud II, confronted the limit of mercenary armies - made up of aristocratic and often uneducated officer and paid (but often unreliable) professional soldiers and press-ganged (and often absent) recruits." [7].

In the 1400s, after the innovation of the cannon and the gun in medieval Europe, the armies in Europe (from the 1500s through the 1700s) were primarily composed of mercenary armies, paid for by the monarchs out of taxes from their state. Guns, cannon, gunpowder, shells, mercenary soldiers were expensive. Monarchies needed taxes, derived from trade in cities; and monarchs promoted the growth of trade and cities. Later in the 1800s, under a social contract between a national government and its citizens, these specific functions were basic to the states-becoming-nations: militarily effective armies with modern weapons, educated officers, and loyal conscripts-paid for by taxes.

Michael Provence wrote: “As in every other European power after the French Revolution, the centerpiece of Ottoman modernization was military conscription and state education. Armies of citizen-conscripts frightened monarchs, due to their revolutionary potential. State education and state nationalism were the two prongs of the approach to acculturate the citizen-soldier to conservative ruling-class hegemony. In the Ottoman realms in 1869, this was implemented in an education law. And after Abdul-Hamids' ascension to the sultanate in 1876, a state identity based on Islam, anti-imperialism, and a series of invented traditions intended to cement loyalty to the state and sovereign." [7].

In both Europe and the Ottoman Empire, the education of citizens was necessary for both for the nation's functioning and for a national culture. Michael Provence wrote: "Patriotism in uniform could bring its social rewards. In Ger- 
many, It provided the potential status as reserve officer for boys who had undergone secondary education to the age of sixteen. In Britain, even clerks and salesmen in the service of the nation could become officers, and in the brutally frank terminology of the British upper class, 'temporary gentlemen'." [7].

The Ottoman Empire divided state education into military and civil tracks. Modern Ottoman State education began with military academies in the imperial capital. Michael Provence wrote: "Ottoman reformers systematized state education with the education law of 1869. Prominent families in provincial capitals like Baghdad, Beirut, and Damascus lobbied tirelessly for elite state civil education institutions. The civil schools were prestigious and drew their students from the families of established ottoman elites." [7].

The Ottoman Empire also followed the rest of Europe in developing a national infrastructure. Michael Provence wrote: "The Ottoman telegraph network was inaugurated during the Crimean war in the 1850s. Within twenty years, the Ottoman network was among the largest in the world. But fast communication alone was not enough without the fast movement of people and goods. Trains, roads, and government building construction came to consume a huge share of Ottoman revenue. All the cities of the former Ottoman realms are full of nineteenth-century buildings and structures still standing, still in use. Modernity meant independence, dignity and survival for the Ottomans." [7].

The Ottoman reforms of the nineteenth century created an educated class of government officials throughout the Empire, whose lives were dedicated to serving the modernizing Ottoman nation. The reforms were effective in the governance of the nation. Even at the fall of the Ottoman Empire in 1918, the collapse was not due to dissolution from within the state but to conquest by nations outside the state. Then the Ottoman Empire/Nation was divided up into Middle Eastern states, by colonialist policies of European nations. Michael Provence wrote: "In the closing decade of the nineteenth century, thousands of young men and women entered modern Ottoman State schools determined to succeed within a state and system they pledged to protect and preserve. The Ottoman State schools and institutions that shaped them gave meaning to their lives and their struggles even after the state they had sworn to serve had disappeared. The story of their lives, times, and struggles properly begins, not with the Turkish or Arab nationalisms they may have eventually espoused, but with the experiences they shared as self-identified protectors and servants of a doomed empire." [7].

\section{Societal Event-Space Analysis of Ottoman Reform}

For analyzing an observed a societal event in the social sciences, one needs a general perceptual space in which to view any historical event as a kind of natural societal experiment. Such a cross-disciplinary, perceptual space has been constructed from three basic dichotomies in the social sciences: individual-society, groups-processes, and reason-action [5]. The societal event of government reform from state to nation, in the nineteenth century Ottoman Empire is analyzed in Figure 3. 


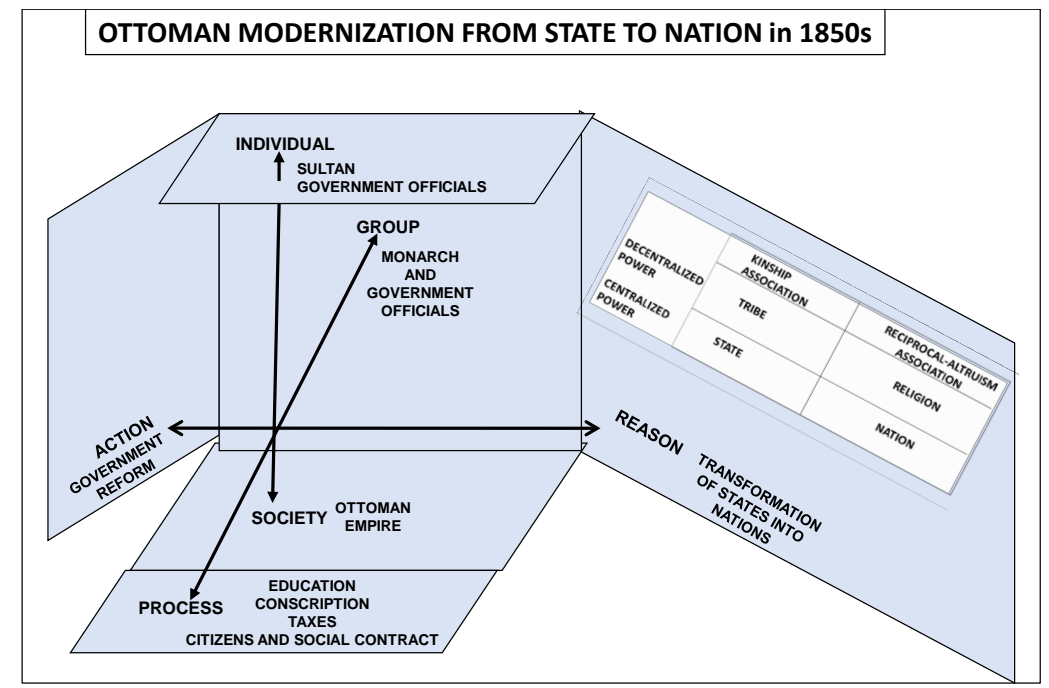

Figure 3. Change-event of Ottoman Empire reforms of 1850.

SOCIETY - The society was the Ottoman Empire, one of the states in the territories of Europe and the Middle East.

ACTION-The action was the reform in the nineteenth century of the Ottoman government (similar to reforms occurring during the same period in other European states, such as France, Germany, and Britain).

REASON-The reasoning behind the reforms was the need to change European states into nations characterized by: 1) a standing army with modern weapons, and mass conscription and 2) educated officers and 3) a loyal citizenry, perceiving a social contract with the government and paying taxes. In the reasoning of European societies at the time, the theoretical distinction between a "state" and a "nation" was important to the thinking of government officials in the Ottoman Empire for introducing national reform.

GROUP-The group involved in European nineteenth century government reform were the government officials of the state, including monarchs, prime ministers, and army officials-a top-down reform.

PROCESS-The process was introducing modern institutions of education, military structure, government bureaucracy, and infrastructures of modern communication and transportation technologies.

INDIVIDUAL - The individuals involved in Ottoman reforms were the head state and the leading and mid-level government officials in the military and civilian administrations.

This analysis emphasizes the six factors (individual-society, group-process, action-reason) which appear in any event which alters a society's structure and functioning. And in that change, one needs to see how these factors interacted to explain the changes which occurred in the society.

In social sciences, explanations are not cause-effect relations between factors but functional relations between factors. Societal science explanations are not methodologically causal between societal factors but, instead, connect functional relationships between societal factors (For example in the connection between 
the factors of society and individual, the ethical relationship is not causal but functional. Societal conditions do not cause ethical behavior in individuals but enable the functioning (or non-functioning) of ethical behavior by individuals. Cause-effect explanations occur only the scientific domains of physics and chemistry and biology and not in the social science disciplines.

The analysis of a societal event in the perceptual space allows explanations to be identified as relations between the six societal factors (society, individual, action, reason, group, process). By constructing a graph of the connections between any two factors, one finds there are fifteen such relationships, which can be used to "explain" the changes of the societal event. Figure 4 shows a diagram of all the relationships connecting two factors in the perceptual space [5].

The fifteen binary relationships are listed for the graphic connections. We apply this explanatory analysis to the Ottoman Reform Event, as shown in Figure 5.

In the modernization of the Ottoman Empire transforming from State to Nation, the following explanation relationships occurred and were important.

1) Ethics: The explanatory relation between factors of the Individual and Society is Ethical. In the Ottoman reform event, the Individual as head of government (Sultan) implicitly offered a kind of social contract to the citizens of the Society of both loyalty and equality-as a new ethical relationship in the reform event of the Ottoman state becoming the Ottoman nation.

3) Institutionalization: The explanatory relation between factors of the Group and Process is the institutionalization of Processes in the activities of Groups. In the Ottoman reform event new laws were passed institutionalizing universal education and conscription for citizens of the Empire.

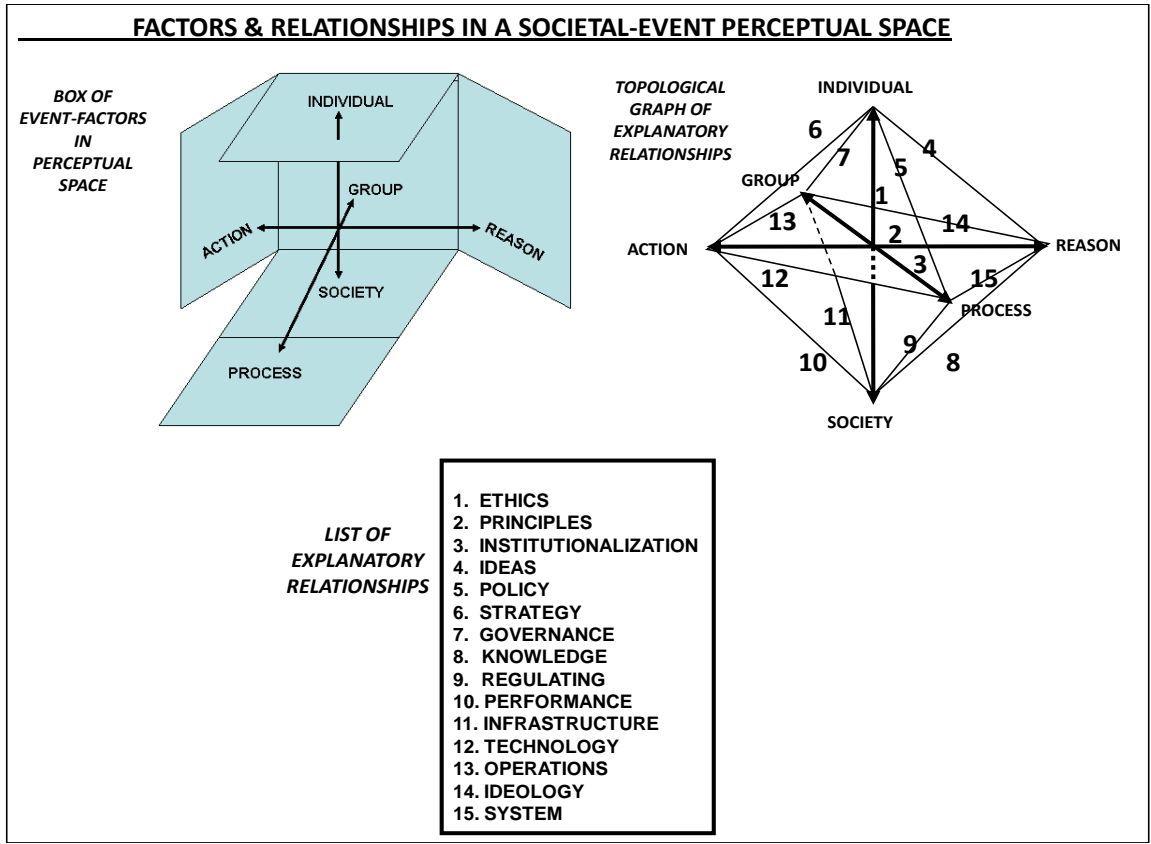

Figure 4. Explanations in a societal change-event as relationships between societal factors. 


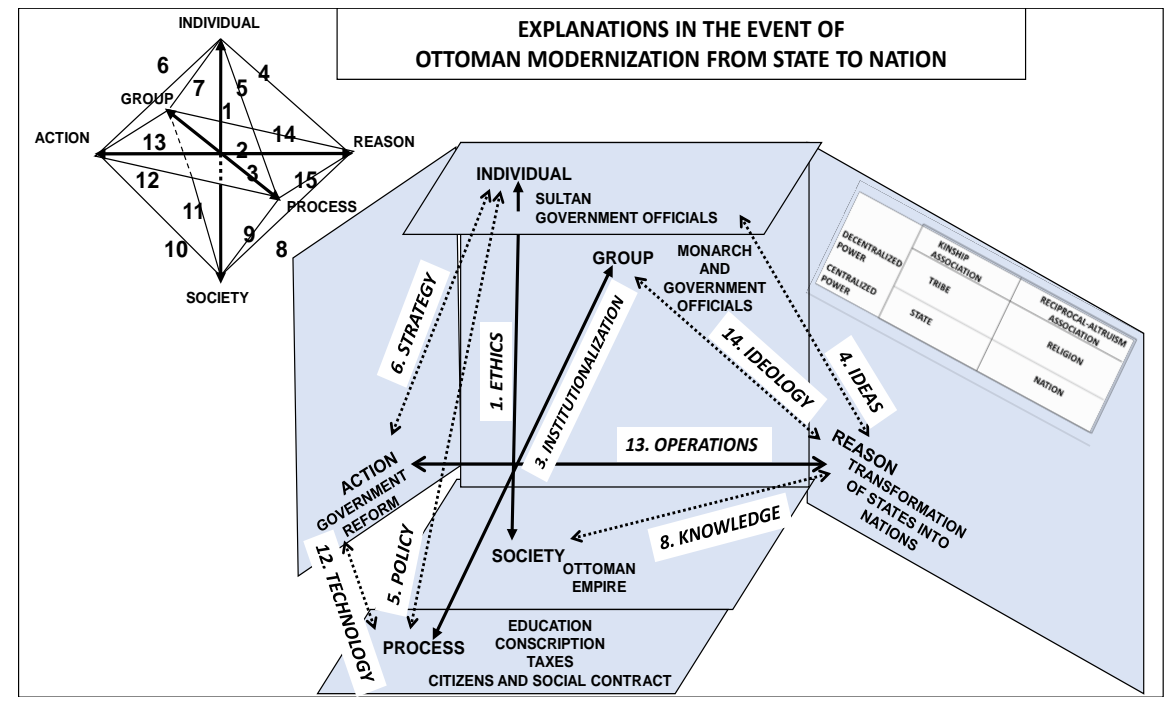

Figure 5. Explanations in the change event of the modernization of the Ottoman Empire.

4) Ideas: The explanatory relationship between the factors of the Individual and Reason is Ideas. In the Ottoman reform event, the idea was that of a "nation" - to transform the Ottoman state into an Ottoman nation. The theory of governmental association underlay the reasoning in nineteenth century Europe about the importance of forming a "nation" from a "state".

5) Policy: The explanatory relation between factors of the Individual and Process is Policy. In the Ottoman reform event, policies for reform were implemented to make citizens of its population, including citizen's duty of conscription and taxation and loyalty.

6) Strategy: The explanatory relation between factors of the Individual and Action is Strategy. In the Ottoman reform event, the government's strategy focused building modern military in the nation through an educated officer staff, conscripted citizen soldiers, and modern military weapons.

8) Knowledge: The explanatory relation between factors of the Reason and Society is Knowledge. In the Ottoman reform event, universal education was implemented with elementary and middle schools for all and with military and civilian academies to build a governmental elite.

12) Technology: The explanatory relation between factors of the Action and Process is Technology. In the Ottoman reform event, military and infrastructure technology was acquired from abroad, principally from Germany.

13) Operations: The explanatory relation between factors of the Action and Reason is Operations. In the Ottoman reform event, infrastructure was built, with a telegraph system for national communication, railroads for land transportation, and steamships for sea transportation.

From these explanations, one can see a concept of "nationalism" was being implemented in the Ottoman Empire, as well as in European nations in the nineteenth century. This concept of "nationalism" centered upon two sub-concepts of "citizenry" and "legitimacy". Michael Provence wrote: "The nineteenth-century 
European state had evolved in the century after the French revolution to become a state that educated, taxed, counted, conscripted, trained, and claimed to act in the name of, and derive its legitimacy from the collective will and sprit of its population." [7].

The European state transformation from state to nation centered upon converting its population to citizens (educated, taxed, counted, conscripted, trained) - this loyalty was claimed by the nation as legitimate in expressing a "collective will and spirit". From the idea of "state" to the idea of "nation" centered upon this redefinition of "governed population" to "citizens".

And this idea of citizen was mythologized by the new nation. Michael Provence wrote: The European combatant states fostered a range of public rituals, origin stories and invented traditions intended to cement loyalty, allegiance and compliance with the state/nation. In the Ottoman state, these centered on Islam, the person and office of the Sultan-Caliph, as successor to the Prophet Muhammad as titular head of the Muslim community. The state also claimed to provide justice and representation to its non-Muslim population" [7].

But the European nationalism did not aim toward a representative democracy, which in nineteenth century Europe had the connotation of "revolutionary". Michael Provence wrote: "The centerpiece of Monarchy still dominated in Europe (except for Britain) and in the Ottoman Empire. Armies of citizen-conscripts frightened monarch and state elites with their revolutionary potential, and state education and state nationalism were the two prongs of the approach to acculturate the citizen-soldier to conservative ruling class hegemony." [7].

In the 1800 s, loyalty-to-the-monarch became loyalty-to-the-nation; and the strength of a nation was in its army. Most European nations were governed by monarchs (except Britain with a constitutional monarch) with an educated military leadership and with a national emphasis upon military strength, built upon a large army of conscripted and loyal citizens. In the next twentieth century, upon this European nationalism legacy, the First World War would begin.

\section{Societal Models as Stasis: Reformed Ottoman Nation}

We can next model this concept of "nationalism" as a societal "stasis" in the reforming Ottoman society of the late nineteenth century. For this we use a taxonomic model of functional systems in a society [5]. Figure 6 shows four interacting subsystems: Economic, Cultural, Political, and Technological.

Government System: Reforms were made in the Government System. In the monarchical government of the Ottoman Empire, reform resulted in a national conscripted army of citizens, managed by an educated officer class. There were no functional parties participating in a representative government, but there were political factions under the absolute monarchy of the government. All the population were now Ottoman citizens and were expected to be loyal patriots.

Cultural System: Reforms were made in the media, with the implementation of telegraph for communication and the railroad and steamships for transportation. 


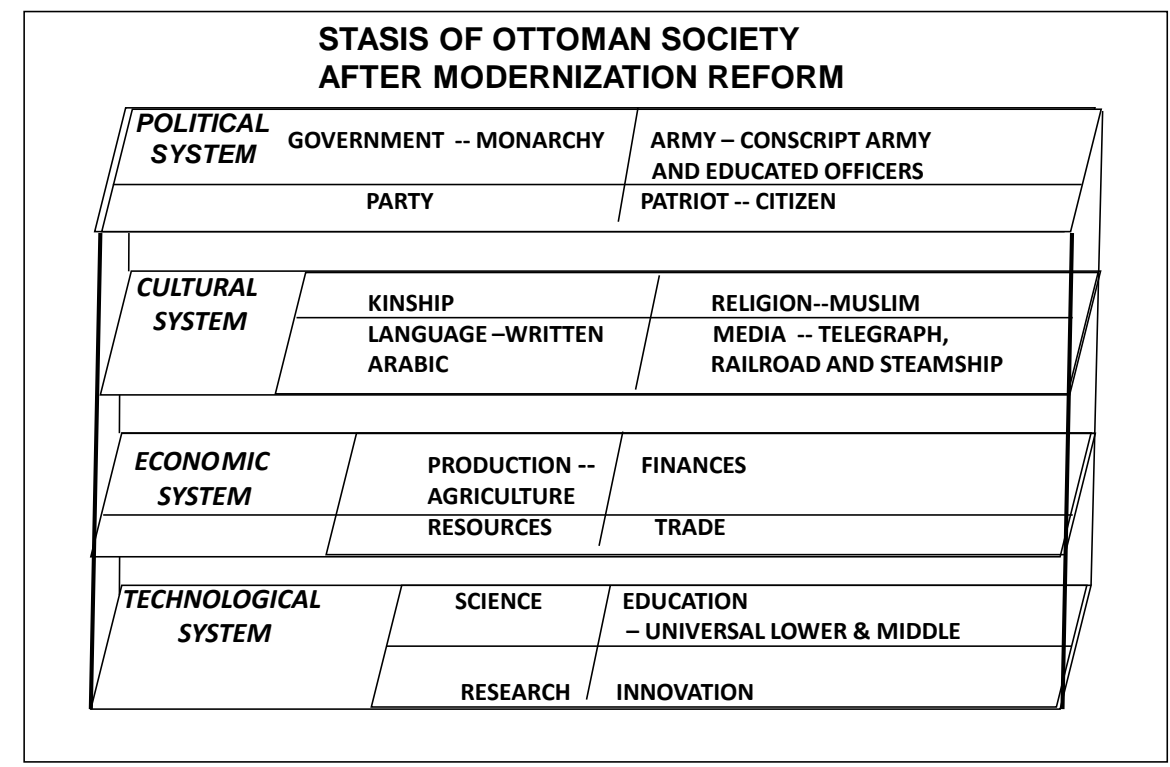

Figure 6. Stasis of ottoman society after modernization reform.

The written language of the Ottoman remained arabic and the religion dominantly muslim.

Economic System: No reforms were made in the economic system of the Ottoman Empire. Agriculture remained the predominate production system; and the European industrial revolution of the nineteenth century did not begin then in the Empire.

Education System: Education was reformed to provide universal education at the lower and middle school levels for all citizens and to provide secondary education in military or civilian acadmies to train a military and bureaucratic elite of leaders.

\section{Historical Timeline of the End of the Ottoman Empire}

We now can depict the historical timeline of the last of the Ottoman Empire, as we earlier discussed, but now with models of the change events and stasis of the society, as shown in Figure 7.

The end of the Ottoman Empire occurred as a result of its entry into World War I and its defeat, along with Germany, in 1918. Beverley Milton-Edwards wrote: "The advent of European political as well as economic control over the region (Middle East) began in earnest in the 1880s with Britain's occupation of Egypt, and reached an apex after the first World War when Britain and France were awarded mandates and protectorates and the right to redraw boundaries and create new nation-states in the region." [9].

In the spring of 1918, World War I ended when the German army collapsed-under a counterattack by American forces, which had reinforced the French army. Earlier in 1917, after the failure of $2^{\text {nd }}$ and $3^{\text {rd }}$ Russian attacks on the Eastern Front of the War, the Russian government collapsed; and the Russian Tsar abdicated. A revolution then resulted in a communist government in 


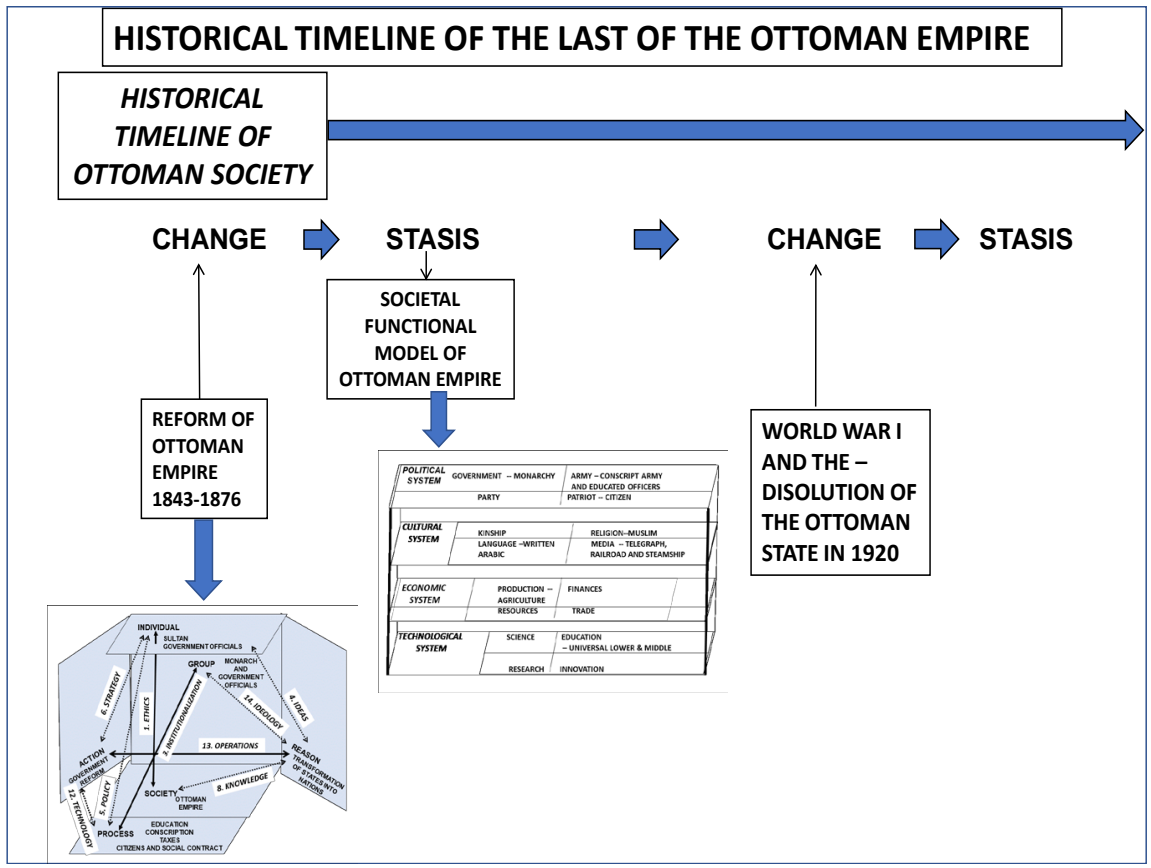

Figure 7. Historical timeline of the last of the Ottoman Empire.

Russia. The next year, the German army collapsed, under a new Western offensive assisted by the American Army. Then the German emperor abdicated, and Germany fell into chaos.

Also in 1918, the British army defeated the Ottoman army in the Middle East, and the Ottoman government collapsed. The victors, Britain and France, had decided to divide up the Ottoman Empire. Michael Provence wrote: "The Ottoman Empire and its realms (was) central to the 1914-18 war. The collapse and disappearance of the Ottoman state was a direct and intended result of the war. British wartime aims, strategies, and agreements envisioned Ottoman partition and imperial expansion into the newly conquered territories as a central goal of the war." [7].

The Ottoman Empire had joined Germany and the Austrian-Hungarian Empire as a "Central Power" against the Great Power combination of Russia, France and Britain. The reason for Ottoman Empire to join with Germany and Austria-Hungarian Empire was that both Russia and Brittan had been seizing Ottoman territories in the nineteenth century and encouraged the break-away of Greece and Balkan states from the Ottomans. Francis Provence wrote: "By 1914, the Ottoman East had been the object of British, French, and Russian imperialist expansion for more than a century." [7]. Germany had been ally of the Ottomans, assisting in modernizing the Ottoman army and in building railroads and telegraph infrastructures.

Actually, war for the Ottoman Empire had begun in 1912, with the newly broken-away Ottoman provinces of the Balkan states seizing more Ottoman territory. Francis Provence wrote: "For Ottoman citizens, summer 1914 was a continuation of war, beginning when Italy invaded Ottoman Libya in 1911, sparking 
a scrabble among smaller European powers for Ottoman territory as the Balkan League alliance of Bulgaria, Serbia, Greece, and Montenegro formed and attacked the Ottoman provinces in Europe in 1912, the Great Powers stood officially aloof. Behind the scenes, however, tensions and ambitions leading to the 1914 outbreak had already emerged." [7].

A British-French plan for dividing up the Ottoman Empire was formalized during the war. In May 1916, the British diplomat, Mark Sykes and the French diplomat, Francois Georges-Picot met in Paris to negotiate a secret pact to partition the Ottoman realms, with France taking Syria and Britain taking Egypt, Palestine, Iraq. This Sykes-Picot agreement was secret and implemented by Britain and France after the war in 1919, as "Mandates" under a new League of Nations.

Beverley Milton-Edwards wrote: "Between 1918 and 1922, the French and British took protectorates and mandates and held them as colonies. The indigenous populations of the Middle East struggled to assert their national rights, their identity and desire for independence. All of them-Arabs, Kurds, and Armenians-failed, as the Europeans met behind closed doors in Paris and San Remo to decide the fate of the region. The end product, the new middle East, was almost unrecognizable from the old empire where rule was Muslim and land was not occupied and settled by strangers from Europe. Under the Ottoman Empire, the Arabs had co-existed with their ethnic and religious neighbors without boldly demarcated borders. Under the new order, entirely new political entities were created." [9].

Beverley Milton-Edwards wrote: "Modern states were created by the British and French. In Transjordan, Syria, Lebanon and Iraq, States were created regardless of the multitudinous ethnic or tribal make-up of the territories." [9].

France created the Syrian state and the Lebanese state from other Ottoman provinces. This put Sunni Muslims together with Shi'a Muslims in Syria. In Lebanon, for example, France put together six communities: Maronite Christians, Druze, Sunni Muslim, Shi'a Muslim, Armenians, and Greek-Orthodox Christians. This mixing set up Iraq, Syria, and Lebanon with tribal/religious conflicts, which where to dominate the regions throughout the twentieth century.

From the Sykes-Picot agreement, Britain created the Iraq state from three Ottoman provinces, which now put Kurds, Sunni Muslims, and Shi'a Muslims in the same state. Britain put an Arab, Faisal, son of Sharif Hussein leader of Mecca, as king of Iraq. Beverly Milton-Edwards wrote: "Faisal was 'gifted' the throne of the new state of Iraq when it was created by the British in 1920. However, the consolation of Iraq for Faisal was bitter, and in Baghdad everyone appeared to know that the power behind the throne still lay with the British. 'Well obviously there were riches in Iraq; there was the oil' Britain created Iraq to control oil found in its southern region.” [9]. Britain also retained its hold over Egypt and divided Palestine into a protectorate and Transjordan, placing the brother of Faisal on its throne.

Only Turkey emerged as an independent nation under the leadership of Mustapha Kemal (1881-1938), an army officer in the Ottoman Empire, who, at the 
dissolution of the Empire established the modern nation of Turkey. Kemal was an officer commanding the defense of the Gallipoli from the Australian-New Zealand invasion in World War I. Kemal had become a national hero, when Ottoman forces defeated the Anzac army.

After the Ottoman defeat, Mustapha Kemal formed a new political party, retreating from Istanbul to Ankara (in the middle of Anatolia). He formed an army of former Ottoman soldiers and defeated an invading Greek Army, which had been sponsored by the British. Then Britain agreed to withdraw from Istanbul in exchange for Kemal's government recognizing the creation of Iraq under British control. Kemal also recognized French control over the newly created mandates of Syria and Lebanon, in exchange for France recognizing the new nation of Turkey under Kemal's leadership.

The tribal group who completely lost, in all these new agreements, was the Kurds, divided then in the new territories of Turkey, Iran, Syria, and Iraq-but with no nation of Kurdistan. Throughout the twentieth century and into the twenty-first century, the Kurdish tribes were almost continually at war with the Turkish government.

Mustapha Kemal called himself "Ataturk" - father of the Turkish nation and instituted reforms to build the modern secular nation of Turkey. Figure 8 analyzes the dissolution of the Ottoman Empire, with only one true "nation" and all other former Ottoman territories as "states" (under the colonial control of Britain and of France).

SOCIETY - The societies involved in dividing the New Middle East were Britain and France partitioning the Ottoman Provinces into new states

ACTION-The states of Iraq, Syria, Lebanon, Transjordan, Palestine, Egypt, and Algeria were established by Britain and France as protectorates and League

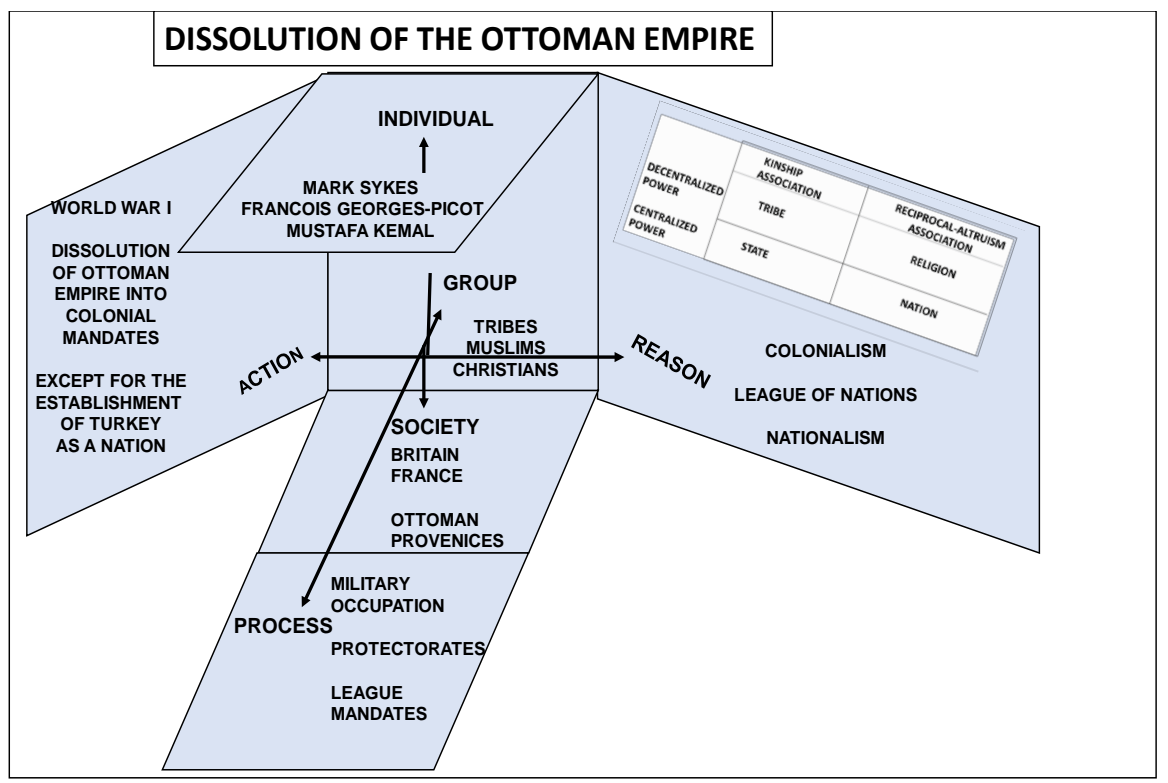

Figure 8. Dissolution of the Ottoman Empire 1918-25. 
Mandates. The Turkish nation was formed under military action against the Greeks and British.

REASON-The reasoning behind the territorial division was "colonialism" as a policy by British and French governments for colonies in the Middle East, as access to oil, land, and trade for British and French citizens. The European reasoning for colonialism ignored the existence and independent aspirations of the different tribes, religious groupings, and ethnic cultures of the region.

GROUP - The groups in the former Ottoman territories included religious groups of Muslims and ethnic tribes, including Arabs, Kurds, and Persians.

PROCESS-The processes were military occupation by British and French forces to force governments over the European protectorates and mandates of the Middle East.

INDIVIDUAL-Prominent individuals involved in organizing the colonial divisions of the Middle East were the British diplomat, Mark Sykes and the French diplomat, Francois Georges-Picot. The Ottoman officer, Mustapha Kemal, militarily established Turkey as an independent nation over the Anatolian territory of the former Ottoman Empire.

\section{Middle East-Colonialism}

In the Sykes-Picot agreement to divide the Ottoman Empire between Britain and France, the European occupation disrupted the ways of life in the Middle East existent over the previous five centuries of the Empire. Beverley Milton-Edwards wrote: "A way of life that had evolved over the many centuries of Ottoman rule was disrupted, fractured and shattered by the colonial powers keen to expropriate traditions and customs, make their mark and shape the region in the European mold of political, economic and social relations. The process of modernization introduced by the colonial powers resulted in social dislocation: with traditional tribal powers undermined by a new class of urban notables, a decile of the rural in favor of the urban, and the creation of new states, such as Iraq and Jordan, where boundaries took little account of pre-existing ethnic, religious and tribal configurations" [9].

The tribal social structures (which had been maintained as functional under the Ottomans) were made "dysfunctional" under colonial rule. And the "urban notables" prospered as parts of puppet governments, under colonial occupation. This did not foster a loyal population, and kept the new colonial territories as "states" (and not as "nations").

The record of colonialism in the Middle East in building stable governments was thus poor. Beverly Milton-Edwards wrote: "The empergence of nationalist sentiment in the Middle East preceded colonial government in the region, but did, in part reflect growing foreign influence from the 1880s onwards. Although the Ottoman Empire was muslim, it required its Arab subjects to learn Turkish, swear allegiance to Turkish governors and rulers and to carry the coin of Turkish rulers. (And as) Azzziz al-Azmeh has argued: Arab nationalism (was added) to the Ottoman reforms in the nineteenth century (which resulted in) a small 
elite class of intellectuals (in the colonialized states)." [9].

Thus from 1918 until the Second World War, the Middle East was plunged into political turmoil, as the colonial powers struggled to exert their power and influence over their subject populations. Beverly Milton-Edwards added: "In the coffee houses and salons of the urban bourgeoisie, a generation of young men, educated in Constantinople, in church schools and in Europe raised the idea of a renaissance of Arab identity. They shared a collective and often invented memory of a golden age of the Arabs or Islam. The vision and aspirations that these turn-of-the century intellectuals promoted can be divided into two themes-Arab nationalism and pan-Islamism." [9].

\section{Expanding the Theoretical Taxonomy of Political Association}

To include these two concepts of an Arab nationalism and a pan-Islamism within the theory of political association, we can expand the four-fold taxonomy of political association into an eight-fold taxonomy-by introducing a third dimension in the taxonomy. As shown in Figure 9, we now re-construct the 2-dimensional taxonomy (Tribe, Religion, State, Nation) into a three-dimensional geometric form with:

1) Kinship-Altruism and Reciprocal-Altruism as opposite directions in one horizontal direction;

2) Centralized-Power and Decentralized-Power as opposite directions in a perpendicular second horizontal direction;

3) Realism and Idealism as opposite directions in a third vertical direction.

Figure 9 depicts a 3-dimensional representation of a theoretical political-association-taxonomy.

Thus, we have a second plane in the taxonomy, now consisting of four more association types: Myth, Political Religion, Nationalism, and Ideology. This plane is a third dimension constructed by a political science dichotomy of Idealism and Realism.

The dichotomy of Idealism-Realism has long existed in political science theory. For example, Bent Flyvbjerg emphasized the importance of the two concepts of Idealism or Realism in political thinking: "a strong civil society is a crucial condition of strong democracy. Empowering civil society is a central concern for the project of democracy. But what is 'civil society'? Most writers on civil society agree that civil society has an institutional core constituted by voluntary associations outside the sphere of the state and the economy. The fundamental act of citizenship in a pluralist democracy is in forming (voluntary) associations the task of maintaining and redefining the boundaries between civil society and state are the two interdependent and simultaneous processes: the expansion of social equality and liberty, and the restructuring and democratizing of state institutions." [10].

The idea of a civil society allows the voluntary association of citizens in a state to act freely and independently of state institutions. Freedom of the citizen to 


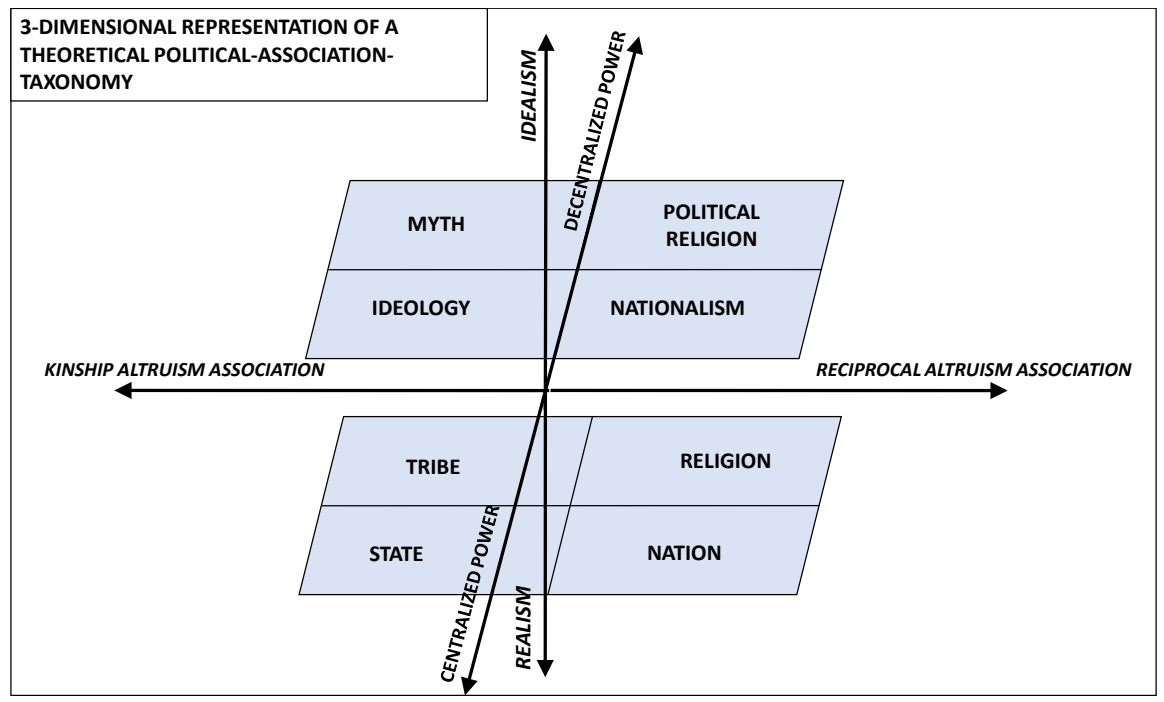

Figure 9. 3-Dimensional representation of a theoretical political-association-taxonomy.

voluntarily associate enables the democratic goals of pursuit of social equality and liberty and limitation of arbitrary and undemocratic exercise of the power of the state. In an authoritarian government, all voluntary associations are controlled by the state, as well as control of state institutions. There is no freedom for citizens in an authoritarian state, only the obedience to dictates of the state.

But the idea of a "civil society" introduces methodological complications in political science research. This idea of a "civil compromise" (civil cooperation or civil collaboration) raises the problem about 1) the existence of power and 2) the distribution of power within society. The idea of a "civil compromise" can have a normative implication: what ought to be a "civil compromise"?

This is the methodological problem of normative judgments versus empirical judgments in social science research-idealism or realism. Within contemporary political science in the last half of the twentieth century, this problem between the ideal or real (normative or empirical) became again the central methodological issue of not only political science but all social science. What is real about the nature of society, and what is ideal? The distinction between societal reality and societal ideal has been and continues to be at the methodological center of all social theory.

Bent Flyvbjerg also provided a nice analysis (within political science) of these two conflicting methodological approaches. Flyvbjerg focused upon the writings of two influential political scientists of the late twentieth century: Jurgen Habermas and Michael Foucault. Flyvbjerg saw their differences as that of methodology:

1) Habermas approached research in political systems as a study of idealism in political theory-normative theory;

2) Foucault approached research in political systems as a study of realism in political theory-empirical theory. 
Jurgen Habermas described political activities by focusing upon and identifying the political ideals around which people gather, associate, and identify. Habermas called this "discourse-ethics" of the politics. By the term "discourse", Habermas indicated that social ideals are discussed openly in the politics as a justification of political action. By the term "ethics", Habermas was indicating that the ideal of the discourse provided an ethical agreement around which a group associates.

Still there is a reality about power in all political situations-the reality of how power is actually used, as opposed to how the power is justified. This, Michael Foucault emphasized, is what should be described as an essential feature of social science methodology. Foucault argued that in any political situation (even focused around a "discourse-ethics") there was also another view to power-which is a "realism" about politics, the "power analytics" of the situation.

Flyvbjerg argued that their two approaches were complimentary and captured a modern political science methodology dichotomy (Idealism or Realism): “The works of Habermas and Foucault highlight an essential tension in modernity. This is the tension between consensus and conflict. Habermas is the philosopher of 'Moralitat' (morality) based on consensus. Foucault is the philosopher of 'wirkliche Historie' (real history) told in terms of conflict and power." [10].

Habermas had followed in the philosophical tradition of Rousseau, in which societal cooperation as a kind of "social contract" should exist between a government and its people. Habermas saw the morality of modern democracy as a "discursive consensus" for a democratic process (which defines the rules of governance in a constitution and provides justification for the exercise of government power by elected officials). This is Habermas' point that political morality as based upon consensus. But how such consensus actually emerges is through conflict-struggle by parties for election, funding of elections by special interests, formulation of laws and enforcement to benefit special interests rather than the general civil public. This is Foucault's point that the actual operation of any real democracy in a society is through conflict and the gaining and exercise of power.

Flyvbjerg's position is that both the Habermas/Rousseau and the Foucault perspectives on consensus and conflict in society are essential to the methodology of the social sciences. The consensus about power in a group is constructed around an ideal expressed in a discourse-ethics of the group (idealism). The reality of how power is really exercised in a group is expressed in the power-analytics of the group (realism). Discourse-ethics is the justification of power; while power-analytics is the exercise of power.

Adding a vertical dimension of the Idealism-Realism dichotomy, the theoretical taxonomy of political association now becomes the eight-fold taxonomy upon which the political concepts of Arab Nationalism and Pan-Islamism can be depicted as in Figure 10.

Along the Realistic dimension of political association in the post-Ottoman Middle East, European Colonialism divided territories into "States", all under 


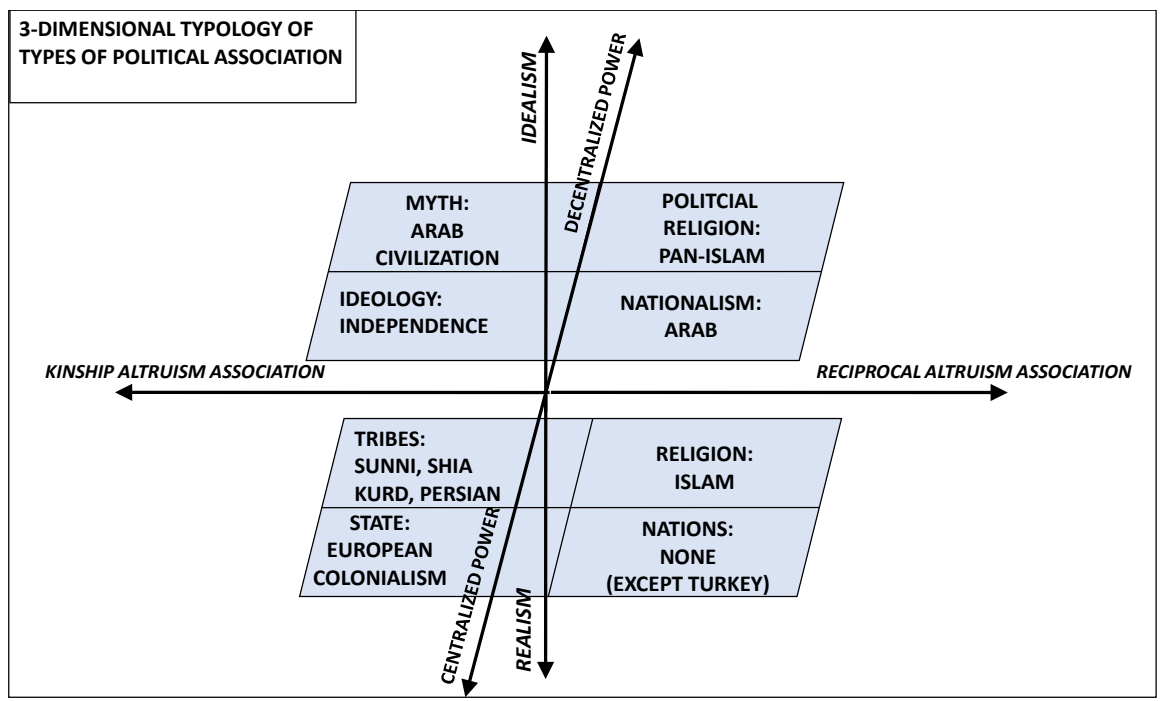

Figure 10. 3-Dimensional typology of types of political association.

British or French control. Yet the people in the states self-associated Realistically, not as citizens of States, but as members of Tribes-dominantly as Sunni, Shia, or Kurds (or others), with Kinship Association or Religious Association. None of these colonial states achieved a Realistic Association as a "Nation"-because participants did not perceive that they were given a reciprocal social contract-by their colonial masters.

Along the Idealistic dimension of political association in the colonial Middle East, an Ideology of Independence spread, organizing either under a mythic Arab Nationalism or a political pan-Islamism. The ideal was to achieve an Arab nationalism-in which Independence would actually be pursued, state by state, after the Second World War.

An important distinction in the typology is between Religion and Political Religion (in which religious motifs are used principally for political purposes). For example, in Syria, ISIS used the religion of Islam and the tribalism of Sunni Islam to justify the seizure of territory and formation of a caliphate state.

\section{The French Colony of Syria}

The name of "Syria" comes from the Semitic word "Siryon"- a word that was in Deuteronomy of the Jewish Bible and referred to Mount Hemon (on the border between modern Syria, Lebanon, and Israel). Britain and France divided the Ottoman region of Syria into different pieces. The British made the eastern desert of the Ottoman Syria into Iraq, as a British mandate; and the British portioned the Southern region of Ottoman Syria into Palestine and Transjordan. The rest of Ottoman Syria became the French colonies of Lebanon and Syria.

Robert Kaplan wrote: "When the French took control of Syria after the First World War, they were fresh from colonizing experiences in Algeria and Tunisia, which had kindled their hostility to Sunni Arab nationalism. In an effort to forestall a rise in Arab nationalism, the French granted autonomous status to Ala- 
wite-dominated area of Latakia and to the Jabal Druze, making their inhabitants completely independent from the Sunni Arabs in Damascus, and answerable to the French only. The Alawites, the Druzes, and the other minorities also paid lower taxes than the majority Sunnis, while getting larger development subsidies from the French government. What is more, the French encouraged the recruitment of Alawites, Druzes, Kurds, and Circassians into their occupation force, the Troupes Speciales du Levant. From then on, the military became a popular career for poor rural Alawites bent on advancement in Syrian society. The majority Sunni Arabs, for their part, were severely repressed. The Damascus region was treated as occupied territory and patrolled by tough Senegalese troops, with help from Alawites, Druzes, and Kurds. The Sunni Arabs felt besieged to a degree they had never experienced under the Ottoman Turks." [11].

Still in the Sunni population of Syria, their sentiment was for pan-Arabism. And the Syria population was divided by sects and religion. Robert Kaplan wrote: "Each of Syria's sects and religions was concentrated in a specific geographical area. In the center was Damascus, which together with the cities of Homs and Hama constituted the heartland of the Sunni Arab majority. In the south was Jabal Druze ('Druze Mountain'), where lived a remote community of heterodox Muslims who were resistant to Damascene rule and had close links across the border with Transjordan. In the north was Aleppo, a cosmopolitan bazaar and trading center containing large numbers of Kurds, Arab Christians, Armenians, Circassians, and Jews, all of whom felt allegiance more to Mosul and Baghdad (both now in Iraq) than to Damascus. And in the west, contiguous to Lebanon, was the mountain stronghold of Latakia, dominated by the Alawites, the most oppressed and recalcitrant of French Syria's Arab minorities, who were destined to have a dramatic effect on postcolonial Syria." [11].

The religious group of Alawites belong to the Muslim division of Shi'ism'. Robert Kaplan wrote: "The Alawites, along with the Druzes and the Isma'ilis (still another Muslim sect in Syria), are remnants of a wave of Shi'ism which swept over the region a thousand years ago. The term 'Alawite' means 'follower of Ali', the martyred son-in-law of Mohammed who is venerated by millions of Shi'ites in Iran and elsewhere. Yet the Alawites' resemblance to the Shi' ites constitutes the least of their heresies in the eyes of Syria's majority Sunni Arabs; far more serious is the Alawite doctrine's affinity with Phoenician paganism-and with Christianity. Alawites celebrate many Christian festivals, including Christmas, Easter, and Palm Sunday, and their religious ceremonies make use of bread and wine." [11].

French colonial rule of Syria did not create a united citizenry. Robert Kaplan wrote: "Sunni paramilitary groups responded by organizing brawls and uprisings against the French in the streets of Damascus. Arguably, not even British Palestine, with its periodic outbursts of communal violence between Arabs and Jews, was as tense and unstable a place as French Syria, whose two colliding forces-minority self-determination and Sunni pan-Arabism-were stimulated rather than restrained by French rule.". 
Thus, one sees that the Ideological orientation of the Sunni Muslims and Alawite Shi'itesin French Syria was focused upon pan-Arabism and pan-Islamism.

\section{Modern States of the Middle East}

In the colonial states of the Middle East between the two World Wars, the new Middle Eastern intellectuals opposed colonial occupation, in all the states created by the Skykes-Picot agreement. And at the end of the Second World War, insurection and international politics forced the British and French to finally yield their North African colonies.

Figure 11 lists the dates after the Second World War, when France and Britain were forced to yield their colonial empires in North Africa. Syria gained independence in 1946.

The map in the next Figure 12 shows the territory of the state of Syria against the territories of surrounding states, after independence.

Then loyalty of the Middle East intellecturals had focused upon "Arab nationalism" and "pan-Islamism". Arab nationalism was an ideal, which had arisen as a response to the collapse of the Ottoman Empire and to the imposition of European colonialism. In the Ottoman Empire, all schools were taught in Turkish. All post Ottoman Middle Easern states were under European collonial occuation. But under occupaion, the Arabic language was revived in the schools and in the press. Arab inellectuals began spreading their ideas of an Arab nation.

Also a pan-Islamic movement, an Arab politization of Islam, rose to challenge the collonial occupation. Beverly Milton-Edwards wrote: "The founder of the pan-Islamic trend was an Iranian-born Muslim Thinker Jama ad-din al-Afgahani (1838-97) who called upon fellow muslims to reassess the role of Islam in their lives. (Later thinkers added) to reacquaint Islam with the immense political, social, and economic changes taking place around them, as a direct result of the colonial experience." [9].

And the colonial repression of Middle Eastern elites between the world wars, then resulted in independence by governments which were not committed to democracy. These were authoritarian regimes, appealing to a justification of

\begin{tabular}{|c|c|c|}
\hline & \multicolumn{2}{|c|}{ INDEPEDENCE OF MIDDLE EASTERN STATES } \\
\hline 1943-46 & LEBANON AND SYRIA & INDEPENDENCE -- FRENCH COLONIALISM ENDS \\
\hline $1946-57$ & JORDAN & INDEPENDENCE -- BRITISH COLONIALISM ENDS \\
\hline $1947-48$ & PALESTINE & PALESTINE PARTIONED - CREATION OF STATE OF ISRAEL \\
\hline 1951 & LIBYA & INDEPENDENCE -- BRITISH AND FRENCY COLONIALISM ENDS \\
\hline 1952 & EGYPT & INDEPENDENCE -- MILITARY COUP AND BRITISH COLONIALISM ENDS \\
\hline 1956 & MOROCCO & INDEPENDENCE -- FRENCH COLONIALISM ENDS \\
\hline 1957 & TUNISIA & INDEPENDENCE -- ITALIAN COLONIALISM ENDS \\
\hline 1958 & IRAQ & INDEPENDENCE -- MILITARY COUP AND BRITISH COLONIALISM ENDS \\
\hline 1961 & KUWAIT & INDEPENDENCE -- BRITISH COLONIALISM ENDS \\
\hline $1962-67$ & YEMEN & INDEPENDENCE -- BRITISH COLONIALISM ENDS \\
\hline 1963 & ALGERIA & INDEPENDENCE -- FRENCH COLONIALISM ENDS \\
\hline 1971 & BAHRAIN & INDEPENDENCE -- BRITISH COLONIALISM ENDS \\
\hline 1971 & QATAR & INDEPENDENCE -- BRITISH COLONIALISM ENDS \\
\hline 1971 & UNITED ARAB EMERATES & INDEPENDENCE -- BRITISH COLONIALISM ENDS \\
\hline
\end{tabular}

Figure 11. Indepence of middle eastern states. 


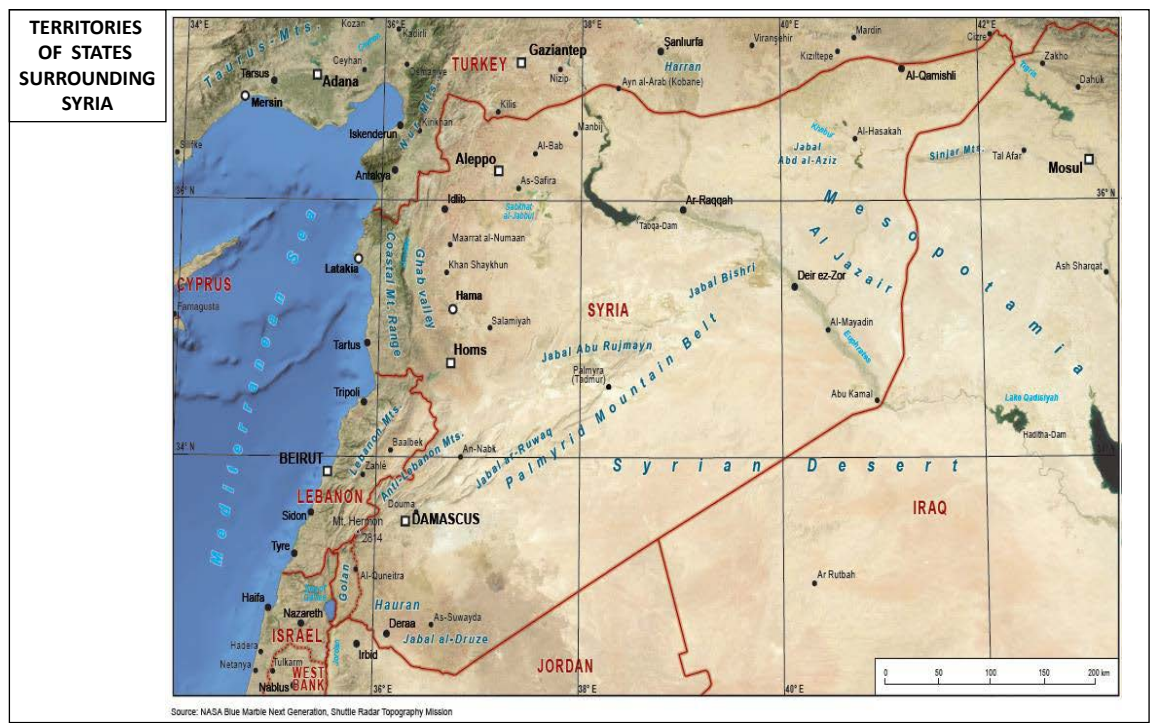

Figure 12. Territories of states surrounding Syria.

governance based upon an Arab nationalism and a Pan-Islamism. Beverly Milton-Edwards wrote: "(In the Middle East) patriotic nationalism is inextricably linked to more than a decade of revolution of independence, which befell the region after the Second World War. Revolutions (a coup d'état or independence) were achieved in countries like Egypt, Lebanon Syria, Iraq, Libya, Tunisia, Morocco Transjordan, Algeria and Yemen. By the early 1970s, a new era had been proclaimed in the region. (Then) other factors (to Arab nationalism and Pan-Islamism) needed to be addressed-including the swing within the Third World as a whole to revolutionary regimes. Also the impact of global capitalism on 'emerging oil economies' in the Arabian Gulf needed to be factored into this 'nationalism' issue. And another factor was important. This is the 'Palestine issue'." [9] (Milton-Edwards, 2018).

After the end of the Ottoman Empire, colonial states were carved out, in such a form that set one Middle Eastern tribe against another. Also colonial powers suppressed indigenous elites, who might have helped evolved Middle Eastern "states" into modern "nations". The exception was Turkey-which Mustapha Kemal had saved from colonial subjugation and did evolve into a nation and not merely a state.

\section{Discussion}

In analyzing failed states of the Middle East, theoretical concepts (in political science) of "state" and "nation" can provide important insights into explaining that history. But such history should begin with the end of the Ottoman Empire, from which a modern Middle East state was carved. Because of the complex details of the government of Syria after independence, we must leave these until a next paper.

Up to independence of the states of the Middle East, we have seen that important theoretical factors can explain why state failure would occur. We have for- 
malized such factors of political association in a 3D taxonomy of associative types: constructed from three basic political science dichotomies of genetic \& reciprocal altruism, centralized \& decentralized power, idealism \& realism of power.

In the $3 D$ theory of political association, along the Realistic dimension of political association in the post-Ottoman Middle East, European Colonialism divided territories into "States", all under British or French control. Yet the people in the states self-associated Realistically, not as citizens of States, but as members of Tribes (dominantly as Sunni, Shia, or Kurds, in Kinship or in Religious association). None of these colonial states achieved a Realistic association as a "Nation"-because participants did not perceive that they were given a reciprocal social contract by their colonial masters.

Along the Idealistic dimension of political association in the colonial Middle East, an Ideology of Independence spreads, organizing either under a mythic Arab Nationalism or a political pan-Islamism. The ideal was to achieve an Arab nationalism-in which Independence would actually be pursued, state by state, after the Second World War.

The importance of the formalization of social science theory into analytical forms is that it facilitates the use of societal histories to "ground" (provide empirical evidence) the validity of a cross-disciplinary social-science theory. The theory used in this research is cross-disciplinary-using from important theoretical insights from the social science disciplines: socio-biology, anthropology, political science, and political economy. Cross-disciplinary social science research is necessary to depict and theoretically explain the historical dynamics of Societies and progress or regress in Civilization.

\section{Conflicts of Interest}

The author declares no conflicts of interest regarding the publication of this paper.

\section{References}

[1] Betz, F. (2019) Theoretical Metric of Civilization: The Case of the International Court of Justice Societal Dynamics. Open Journal of Social Sciences, 7, 1-20. http://www.scirp.org/journal/jss

[2] Fukuyama, F. (2014) Political Order and Political Decay. Farrar, Straus and Giroux, New York.

[3] Fukuyama, F. (2011) The Origins of Political Order: From Pre-Human Times to the French Revolution. Farrar, Straus and Giroux, New York.

[4] Friedman, T. (1989) From Beirut to Jerusalem. Farrar, Straus and Giroux, New York.

[5] Betz, F. (2011) Societal Dynamics. Springer, New York.

[6] Parsons, T. (1967) The Structure of Social Action. Free Press, New York.

[7] Provence, M. (2017) The Last Ottoman Generation and the Making of the Modern Middle East. Cambridge University Press, Cambridge. 
https://doi.org/10.1017/9781139049221

[8] Rousseau, J.-J. and Cranston, M. (1968) The Social Contract. Penguin Books for Philosophy.

[9] Milton-Edwards, B. (2018) Contemporary Politics in the Middle East. 4th Edition, Polity Press, Cambridge.

[10] Flyvbjerg, B. (1998) Habermas and Foucault: Thinkers for Civil Society? British Journal of Sociology, 49, 210-233. https://doi.org/10.2307/591310

[11] Kaplan, R.D. (1993) Syria Identity Crisis. The Atlantic. https://www.theatlantic.com/magazine/archive/1993/02/syria-identity-crisis/303860 